\title{
Autofermentation of Chamomile Ligulate Flowers Promote Antitumor Effects in vitro
}

\author{
Marijana Jukić, ${ }^{1 \#}$ Aleksandra Cvetanović, ${ }^{2 \#}$ Katarina Mišković Špoljarić, ${ }^{1}$ \\ Saša Savić, ${ }^{3}$ Jaroslava Švarc-Gajić, ${ }^{2}$ Zoran Zeković ${ }^{2}$ and Ljubica Glavaš-Obrovac ${ }^{1, *}$ \\ ${ }^{1}$ Department of Medicinal Chemistry, Biochemistry and Clinical Chemistry, Faculty of Medicine, \\ J. J. Strossmayer University of Osijek, J. Huttlera 4, HR-31000 Osijek, Croatia \\ ${ }^{2}$ Department of Pharmaceutical Engineering and Biotechnology, Faculty of Technology, University of Novi Sad, \\ Bulevar cara Lazara 1, 21000 Novi Sad, Serbia \\ ${ }^{3}$ Faculty of Technology, Bulevar Oslobođenja 124, 16000 Leskovac, Serbia \\ * Corresponding author: E-mail: lgobrovac@mefos.hr; \\ Tel.: +385-91-224-1446; Fax: +385-31-399-613.
}

Received: 10-11-2018

\# These authors contributed equally to this work.

\begin{abstract}
In the frame of this paper, the enzyme-assisted hydrolysis coupled with ultrasound and Soxhlet extraction was applied in order to get extracts of chamomile ligulate flowers (CLF). Obtained extracts were characterized in terms to their apigenin and apigenin glucoside composition, as well as antiproliferative potential against tumour cells. Antioxidant activity was determined by two different assays based on different mechanisms showing that autofermented extracts have higher reduction potential. Autofermented extracts prepared by ultrasound and Soxhlet extraction had a stronger impact on the treated carcinoma (HeLa and NCI-H358) and leukemia (K562) cells' growth reduction in comparison to the native extracts, $30-35 \%$ greater inhibition at the lowest concentration $(0.01 \mathrm{mg} / \mathrm{mL}$ ), in two observed time points (48 and 72 h). Leukemia cells are more sensitive to all tested extracts. The autofermented CLF extracts with highest antiproliferative efficacy induced morphological changes and apoptosis in the HeLa cells. Obtained results clearly showed that the combination of enzymatic hydrolysis with cavitation phenomenon results in extracts with higher apigenin content and increased biological potential.
\end{abstract}

Keywords: Chamomile flowers; extraction; apigenin; antiproliferative activity; apoptosis

\section{Introduction}

It is well known that some natural plant compounds exhibit positive impact on human health demonstrating additive or synergistic diseases-fighting activities. ${ }^{1}$ Flavonoids, especially flavons, flavonols and flavanons, are often key bioactive compounds for antioxidant and anticancer effects. $^{2,3}$

Apigenin (4,5,7-trihydroxyflavone) is a flavon with relatively low molecular weight. Different studies have shown that apigenin demonstrates broad spectrum of beneficial effects being considered as a molecule with promising pharmacological and biological characteristics. Studies have shown that apigenin is a potent antioxidant, antiviral, antimicrobial and chemo preventive agent. ${ }^{4-7}$ In the structure of this compound three hydroxyl groups together with double bonds at C2 and C3 are present. Such chemical structure provides that apigenin can acts as a phytoestrogen. Furthermore, high cytotoxic activity of apigen$i^{8}$ was proved in numerous studies. It is capable to induce apoptosis in different tumour cells like monocytic and lymphocytic leukemia cells, cervical, lung, breast, and colon carcinoma cells as well. ${ }^{6,9,10}$ Conducted studies have provided data related to its chemoprotective effects. It was demonstrated that apigenin are able to block signal transduction pathways in different models of prostate cancer. ${ }^{11}$ Further, treatment of prostate cancer with apigenin can stop the cell cycle in the GO-G1 phase. ${ }^{12,13}$ It can inhibit 
growth of cancer cells and induce apoptosis in them; however it does not influence the growth of normal cells. ${ }^{14}$ Thus, it is considered as high-selective molecule. Low toxicity of apigenin was also proven. In fact, it shows lower toxicity in comparison to some other structurally similar molecules (quercetin, kaempferol, luteolin, and others). ${ }^{15}$

Apigenin is common constituent of different fruits, vegetables, medicinal plant, teas or other plants based beverages. However, one of the most common dietary sources of apigenin is herbal tea prepared from chamomile (Matricaria chamomilla L.). The chamomile inflorescences (socalled anthodia), consisting of white (ligulate) and yellow (tubulare) flowers, contain different chemical constituents. Apigenin is present only in chamomile ligulate flowers (CLF) where it can be accumulated in a different form: (1) form of free aglycone; (2) form of glycoside - apigenin-7-O- $\beta$-glycoside (Ap-7-Glc); (3) form of different acetylated derivatives of Ap-7-Glc. ${ }^{16}$ Earlier research has shown content of free apigenin is much lower than content of its bound forms. ${ }^{17}$ However, from the biological point of view, high concentration of free apigenin in chamomile extracts is of great importance. An increase of its content in starting plant material and further in extracts is very notable task and different method for hydrolysis of apigenin glycosides into aglycone have been reported in the literature.

In this study, apigenin was liberated from its glycosides by enzymatic biotransformation, i.e. autofermentation. The conducted process was based on activation of $\beta$-glucosidase, an enzyme which is naturally present in chamomile and has the ability to hydrolyse apigenin glycosides to apigenin. Autofermented chamomile ligulate flowers (A-CLF) together with native ones (N-CLF) were used for the extracts preparation. In order to ensure the maximal content of desired compound in the final extract, novel extraction technique was applied. Namely, enzyme-assisted hydrolysis was combined with cavitation phenomenon in ultrasound extraction system. Simultaneously, extraction was done by reference technique (Soxhlet extraction), as well. Moreover, green and safe solvents were used to obtained extracts with improved apigenin content, which is in agreement with the efforts of modern science to produce safe and healthy products without the traces of organic/toxic solvents. Detailed chemical profiles of the obtained extracts were defined by UHPLC-MS-MS analysis. The bio-potentials of native (N-CLF) and autofermented (A-CLF) extracts were compared, including evaluation of apoptosis and morphological changes which had been influenced by extracts.

\section{Exsperimental}

\section{1. Sample Preparation}

Dry plant material (CLF) was purchased from the Institute of Field and Vegetable Crops, Bački Petrovac, Ser- bia. The autofermentation of CLF was performed in the manner previously described elsewhere. ${ }^{18}$ Obtained autofermented (A-CLF) as well as native (N-CLF) flowers were used for extraction process.

\section{2. Ultrasound-assisted extraction (UE)}

The UE was carried out in an ultrasonic bath (Branson, USA) at a frequency of $55 \mathrm{~Hz}$. N-CLF and A-CLF were extracted by both ethanol and water. A mass of plant material used for the extraction was $5 \mathrm{~g}$, while volume of the solvent was $250 \mathrm{~mL}$. UE was performed within $40 \mathrm{~min}$ utes. Obtained extracts were filtered and dried at $40{ }^{\circ} \mathrm{C}$. Extraction runs were performed in triplicates.

\section{3. Soxhlet extraction (SE)}

Plant samples (N-CLF or A-CLF) were subjected to extraction in a Soxhlet extractor by using ethanol as a solvent. Extraction process was carried out for eight hours, i.e. until the solvent discoloration. After cooling, the solvent was removed from obtained extracts by evaporation and the extracts were dried at $40{ }^{\circ} \mathrm{C}$. Thus obtained SE extracts were kept in a glass vessel and stored at $4{ }^{\circ} \mathrm{C}$ until analysis. Extraction runs were performed in triplicates.

\section{4. Determination of the total extraction yield, total phenols (TP) and flavonoids (TF) content}

Determination of the total extraction yield was carried out according to the method previously described in $\mathrm{Ph}$. Jug. IV. ${ }^{19}$ Yield of each extract was expressed as mass of dry extract per $100 \mathrm{~g}$ of dry plant material (g/100 g DP).

Total phenols (TP) and flavonoids (TF) content was determined according to the methods previously described by Singleton and Rossi ${ }^{20}$ and Markham, ${ }^{21}$ respectively. In case of phenols content, the obtained results were expressed as a mass of chlorogenic acid equivalents (CAE) per g of dry extract (mg CAE/g). The content of total flavonoids in examined extracts was expressed as a mass of rutin equivalents (RE) per $\mathrm{g}$ of dry extract (mg RE/g). All measurements were done in triplicates.

\subsection{TLC-UV Determination of Apigenin and Apigenin-7-O-glucoside Content}

TLC-UV measurement of apigenin and Ap-7-Glc content was done according to the procedure previously described elsewhere. ${ }^{22}$ Mobile phase was made by mixing toluene, methyl ethyl ketone and methanol in the ratio of 55:30:15 (v/v/v), while stationary phase was silica gel $\mathrm{GF}_{254}$ (thickness of the layer was $0.5 \mathrm{~mm}$ ). Standard compounds (apigenin and Ap-7-Glc; analytical grade of purity $\geq 99 \%$ ) were dissolved in ethanol and used for calibration curve 
preparation. Calibration curve for apigenin was defined for the concentration range $0.02-0.1 \mathrm{mg} / \mathrm{mL}\left(C_{\text {Apigenin }}=\right.$ $\left.=\frac{A-0.03}{6.91}, \quad \mathrm{R}^{2}=0.9981\right)$. For Ap-7-Glc this concentration range was $0.01-0.09 \mathrm{mg} / \mathrm{mL}$, and the curve had the follow-

ing expression: $C_{A p-7-G l c}=\frac{A-0.03}{2.43},\left(\mathrm{R}^{2}=0.9978\right)$.

\section{6. UHPLC-DAD-HESI-MS/MS Analysis}

The analysis was performed by using Thermo Scientific liquid chromatography system (UHPLC) (Thermo Fisher Scientific, San Jose, California, USA). Xcalibur (version 2.2 SP1.48) and LCQ Fleet (version 2.7.0.1103 SP1) software were used for instrument control, data acquisition and data analysis. Separations were performed on a Hypersil gold C18 column $(50 \times 2.1 \mathrm{~mm}, 1.9 \mu \mathrm{m})$. The used mobile phase was consisted of $(\mathrm{A})$ water $+0.2 \%$ formic acid and (B) acetonitrile. The volume of $5 \mu \mathrm{L}$ of each extract was injected into the system. The column was termostated at $25^{\circ} \mathrm{C}$ and the analysis was performed according to the method previously described in the literature. ${ }^{18,23}$ Detected compounds were identified according to corresponding spectral characteristics: mass spectra, accurate mass and characteristic fragmentation. Quantification of apigenin and Ap-7-Glc was made by using the external standard method.

\section{7. Antioxidant Activity}

The ability of the extracts to act as antioxidants was determined by two different assays: DPPH and reducing power methods. DPPH test was done followed the method of Espín ${ }^{24}$ while reducing powers ability was measured according to the $\mathrm{Oyaizu}^{25}$ method. The obtained results were expressed as $\mathrm{IC}_{50}(\mathrm{mg} / \mathrm{mL})$ and $\mathrm{EC}_{50}(\mathrm{mg} / \mathrm{mL})$ values, respectively (Table 1).

\section{8. Cell Lines and Culturing}

The experiments were carried out on cervix adenocarcinoma (HeLa), bronhoalveolar carcinoma (NCI-H358), chronic myeloid leukemia in blast crisis (K562), and normal Madin-Darby canine kidney fibroblast like cells (MDCK I; $p=33-35$ ). HeLa and MDCK I cells were cultured in DMEM supplemented with $10 \%$ heat-inactivated FBS and $2 \mathrm{mM}$ glutamine. NCI-H358 and K562, were grown in RPMI 1640 medium supplemented with $10 \%$ FBS, $2 \mathrm{mM}$ glutamine, $10 \mathrm{mM}$ sodium pyruvate and $2 \mathrm{mM}$ HEPES. The cells were grown as monolayers or suspensions in tissue culture flasks (BD Falcon, Germany) in the humidified atmosphere under the conditions of $37{ }^{\circ} \mathrm{C} / 5 \%$ of $\mathrm{CO}_{2}$ gas in the $\mathrm{CO}_{2}$ incubator (IGO 150 CELLlife, ${ }^{\mathrm{TM}}$ JOUAN, ThermoFisher Scientific, Waltham, MA, USA). The trypan blue dye exclusion method was used to assess cell viability.

\section{9. Cytotoxicity Evaluation}

The effects of observed CLF and A-CLF extracts on the growth of normal and tumor cells were determined using the MTT assay. The adherent cells, MDCK I, HeLa, and NCI-H358, were seeded in 96 micro-well plates at concentration of $2 \times 10^{4}$ cells $/ \mathrm{mL}$. The cells were incubated during the night in the $\mathrm{CO}_{2}$. Afterwards, the cells were treated with extracts and incubated for 48 and $72 \mathrm{~h}$. Immediately after, medium was replaced with MTT solution (5 $\mathrm{mg} / \mathrm{mL}$ ) and the resulting formazane crystals were dissolved in DMSO. In case of leukemia cells, the cells were seeded at the plates in the concentration of $1 \times 10^{5}$ cells $/ \mathrm{mL}$, and incubated for $72 \mathrm{~h}$. After that, MTT solution (5 $\mathrm{mg} / \mathrm{mL}$ ) was added to the each well and incubation was performed for $4 \mathrm{~h}$ in $\mathrm{CO}_{2}$ humidified atmosphere. In order to dissolve water-insoluble MTT-formazane crystals, $10 \%$ SDS with $0.01 \mathrm{M} \mathrm{HCl}$ was added to each well. The absorbance was read at $595 \mathrm{~nm}$ on ELISA microplate reader.

All experiments were performed at least three times in triplicates. The percentage of cell growth was calculated in the manner given in the literature. ${ }^{26}$

The results were expressed as $\mathrm{GI}_{50}$ value, i.e. as a concentration of the extract which are able to reduce the cell growth by $50 \%$.

\section{10. Detection of Apoptosis}

The ApoAlert Annexin V-FITC staining kit was used to detect apoptosis at the single cell level. Experiments were performed according to manufacturer's instructions, with modification in propidium iodide concentration (reduced $1.5 \mathrm{x}$ ). Briefly, $1 \times 10^{5}$ cells $/ \mathrm{mL}$ HeLa cells were seeded on 8-wells chamber slides with silicon borders and incubated in DMEM overnight. Growing medium was replaced with a fresh medium containing $\mathrm{GI}_{50}$ concentration of A-UE $(0.098 \mathrm{mg} / \mathrm{mL})$ and A-SE extracts $(0.079 \mathrm{mg} /$ $\mathrm{mL}$ ) for 24 and $48 \mathrm{hrs}$, respectively. The $\mathrm{GI}_{50}$ concentration $(0.008 \mathrm{mg} / \mathrm{mL})$ for commercially available apigenin was determined on HeLa cell line by MTT test.

The cells were analysed by fluorescent microscope in a combination with appropriate filters $\left(\lambda_{\text {exc }}=450-490 \mathrm{~nm}\right.$; $\left.\lambda_{\mathrm{em}}=520 \mathrm{~nm}(\mathrm{f} 3) ; \lambda_{\mathrm{exc}}=530-585 \mathrm{~nm} ; \lambda_{\mathrm{em}}=615 \mathrm{~nm}(\mathrm{f} 2)\right)$.

\section{11. Morphological Changes}

The HeLa cells were seeded in 6-wells plate at a concentration $1 \times 10^{5}$ cells $/ \mathrm{mL}$ and incubated overnight in $\mathrm{CO}_{2}$ incubator. The cells were exposed to the $\mathrm{GI}_{50}$ concentration of A-UE $(0.098 \mathrm{mg} / \mathrm{mL})$ and A-SE extracts $(0.079 \mathrm{mg} / \mathrm{mL})$ for 48 and $72 \mathrm{hrs}$ and monitored by inverted microscope.

\section{12. Statistical Analysis}

Statistical analysis was performed by Statistic 11.0 for Windows. Data are expressed as a mean value (X) and 
standard deviation (SD) of three independent experiments done in triplicate. A nonparametric Mann-Whitney test was applied and statistical significance was set at the $\mathrm{p}<0.05$ to compare treated cells to control (nontreated) cells

\section{Results and Discussion}

\section{1. Content of Apigenin and Apigenin-7- O-glucoside (Ap-7-Glc) in the Obtained Extracts}

Due to the considerable bioactivity of apigenin we performed the bioconversion of Ap-7-Glc in the plant material prior to extraction process to increase concentration of its free form. In order to define extraction method that would provide the highest yield of apigenin, both, native and autofermented chamomile ligulate flowers, were extracted by applying ultrasound-assisted and Soxhlet extractions. The ultrasound extraction represents a modern technique in which desorption of the analytes from the matrix is enhanced due to cavitation phenomenon. However, cavitation can also provoke the destruction of the target analytes. From this reason, scrutiny of the polyphenols' behaviour in different extraction systems is necessary. For this purpose, the Soxhlet extraction, as a reference technique, was used. Apart of the technique, used solvent has multiple influence on extraction efficiency, and choosing the optimal solvent or their mixture is one of the most important task in the extraction process of bioactive molecules.

Ethanol and water, as well as their mixture are classified as GRAS (generally recognized as safe) and suitable for the recovery of nutraceuticals. Even ethanol is not highly selective for phenols, its use is preferable in comparison to other organic solvents, especially for food and pharmaceutical products. For these reasons, ethanol was used for sonification of native (N-UE) and autofermented (A-UE) CLF. The same solvent was used for the Soxhlet extraction of nonfermented (N-SE) and autofermented (A-SE) samples. Additionally, water was used as a solvent for ultrasound extraction of native $\left(\mathrm{N}-\mathrm{UE}_{\mathrm{W}}\right)$, as well as autofermented $\left(\mathrm{A}-\mathrm{UE}_{\mathrm{W}}\right) \mathrm{CLF}$.

The first step in our research was to determine the success of the fermentation process. For that reason, $\mathrm{N}-\mathrm{CLF}$ and A-CLF extracts were subjected to TLC-UV analysis. Appearance of obtained TLC chromatogram suggested that apigenin was present in all samples and the intensity of its spots was stronger in autofermented samples than in native ones. The Ap-7-Glc was also present in all extracts, but on contrary to the apigenin, the intensity of Ap-7-Glc spots in A-CLF samples was lower. Although literature data suggest that apigenin is poorly soluble in water, ${ }^{11}$ apigenin was present in CLF water extracts. Presence of the apigenin in water extracts was previously reported in the literature. ${ }^{11}$ Taking into account that concentration of apigenin in hot water tea could be up to $1.2 \%$ it can be assumed, that specific experimental condition could isolate this flavon. Taking into account that physico-chemical properties of solvents are altered in the ultrasonic field and very often the solvating properties are enhanced, we suppose that the ultrasound modified solvating properties of water. Nevertheless, the concentration of both flavonoid forms was higher in ethanolic samples. As presented in Table 1, results of quantifications of Ap-7-Glc and apigenin show increased concentration of apigenin after fermentation process.

Table 1. Content of apigenin and apigenin-7-O-glucoside in obtained extracts.

\begin{tabular}{ccc}
\hline Extracts & Apigenin $(\mathbf{m g} / \mathbf{g})$ & Ap-7-Glc $(\mathbf{m g} / \mathbf{g})$ \\
\hline $\mathbf{A}-\mathbf{U E}^{\mathbf{1}}$ & $2.51 \pm 0.18$ & $1.35 \pm 0.05$ \\
$\mathbf{N}-\mathbf{U E}^{2}$ & $0.39 \pm 0.07$ & $0.89 \pm 0.13$ \\
$\mathbf{A}^{\mathbf{S}}$ & $2.42 \pm 0.02$ & $1.31 \pm 0.09$ \\
N-SE $^{4}$ & $0.02 \pm 0.00$ & $0.06 \pm 0.02$ \\
A-UE $_{\mathbf{W}}{ }^{\mathbf{5}}$ & $1.37 \pm 0.07$ & $0.91 \pm 0.06$ \\
N-UE $_{\mathbf{W}}{ }^{6}$ & $0.18 \pm 0.01$ & $0.53 \pm 0.02$ \\
\hline
\end{tabular}

Data represent mean value of three independent experiments done in triplicate.

${ }^{1}$ A-UE ethanol extract of autofermented flowers prepared by ultrasound extraction; ${ }^{2} \mathrm{~N}$-UE ethanol extract of native flowers prepared by ultrasound extraction; ${ }^{3} \mathrm{~A}-\mathrm{SE}$ ethanol extract of autofermented flowers prepared by Soxhlet extraction; ${ }^{4} \mathbf{N}$-SE ethanol extract prepared from native flowers by Soxhlet extraction; ${ }^{5} \mathbf{A}-\mathbf{U E}_{\mathrm{W}}$ aqueous extract prepared from autofermented flowers by ultrasound extraction; ${ }^{6} \mathbf{N}-\mathbf{U E}_{\mathrm{W}}$ aqueous extract prepared from native flowers by ultrasound extraction

However, the biotransformation of Ap-7-Glc was not complete, possibly due to the presence of other apigenin derivatives. Namely, according to the literature data, chamomile may contain up to 12 different derivatives of Ap-7Glc. ${ }^{16}$ Thus it can be assumed that during the fermentation those derivatives, in first place mono- and diacetylated, were transformed into Ap-7-Glc. In this way, during the fermentation a particular amount of Ap-7-Glc was transformed into apigenin.

Based on the results presented in the Table 1, it is evident that the content of apigenin was much higher in A-CLF. This confirmed successful hydrolysis of apigenin glucosides in chamomile by the plants' own enzymes. Although, TLC was performed for fast screening of target substances, there was need for more relevant analysis like an UHPLC-MS-MS analysis which was performed with two selected samples (A-UE and N-UE). The content of target compounds in these samples was previously reported ${ }^{18}$ and its chromatograms are presented in the Fig. 1. Quantification of apigenin and Ap-7-Glc was made by using the external standard method. Obtained results were in accordance with those obtained by the TLC (Table 1). 
a)

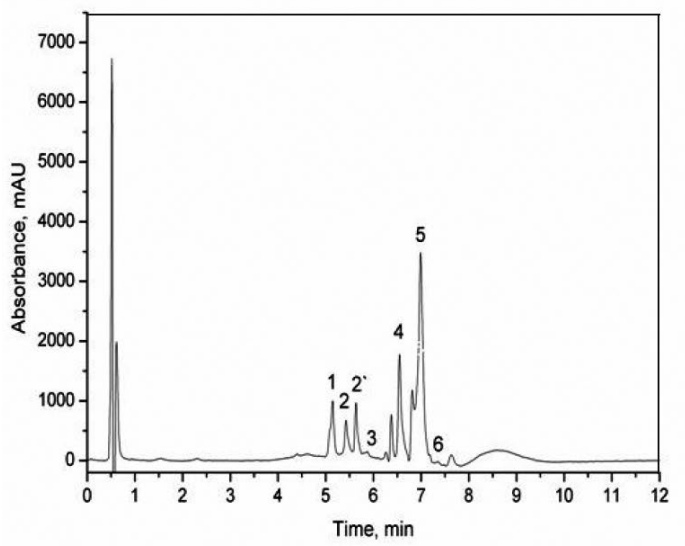

b)

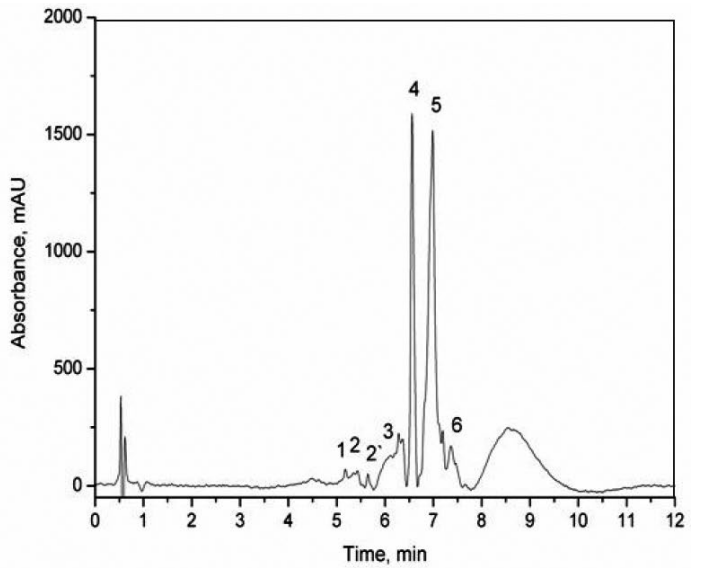

Figure 1. HPLC chromatograms of native (A) and fermented (B) chamomile extract obtained by UE technique. Identified compounds are labelled as peaks 1-6: 1- apigenin-7-O-glucoside; 2, 2'- derivate of apigenin-7-O-glucoside; 3-apigenin; 4, 5- derivate of flavonoids; 6-chlorogenic acid

\section{2. Extraction Yield, Total Phenols (TP) and Flavonoids (TF) Content}

In order to achieve the highest yields of biologically active compounds in obtained extracts the comparative analysis of solvents and extraction techniques for their isolation was done. The total extraction yields, TP and TF contents in different extracts are shown in the Table 2.

Table 2. Total extraction yield, total phenols and flavonoids contents in the obtained extracts

\begin{tabular}{lccc}
\hline Extracts & $\begin{array}{c}\text { Total } \\
\text { extraction yield } \\
(\% ; \mathbf{w} / \mathbf{w})\end{array}$ & $\begin{array}{c}\text { Total phenols } \\
\text { content } \\
(\mathbf{m g} \text { CAE/g) }\end{array}$ & $\begin{array}{c}\text { Total flavonoids } \\
\text { content } \\
(\mathbf{m g} \text { RE/g) }\end{array}$ \\
\hline A-UE & $31.00 \pm 1.56$ & $198.64 \pm 0.93$ & $39.10 \pm 0.26$ \\
N-UE & $27.80 \pm 0.17$ & $133.26 \pm 1.24$ & $31.27 \pm 0.11$ \\
A-SE & $28.93 \pm 0.18$ & $198.07 \pm 1.10$ & $38.98 \pm 0.09$ \\
N-SE & $27.62 \pm 0.81$ & $132.04 \pm 1.04$ & $32.35 \pm 0.21$ \\
A-UE & $30.50 \pm 0.57$ & $135.09 \pm 0.45$ & $35.63 \pm 1.59$ \\
N-UE $_{W}$ & $31.70 \pm 0.27$ & $130.82 \pm 0.96$ & $29.80 \pm 0.17$ \\
\hline
\end{tabular}

Data represent mean value of three independent experiments done in triplicate.

A-UE ethanol extract of autofermented flowers prepared by ultrasound extraction; N-UE ethanol extract of native flowers prepared by ultrasound extraction; A-SE ethanol extract of autofermented flowers prepared by Soxhlet extraction; N-SE ethanol extract prepared from native flowers by Soxhlet extraction; $\mathbf{A}-\mathbf{U E}_{\mathrm{W}}$ aqueous extract prepared from autofermented flowers by ultrasound extraction; $\mathbf{N}-\mathbf{U E}_{\mathrm{W}}$ aqueous extract prepared from native flowers by ultrasound extraction

Total extraction yield was between $27.62 \%$ (in case of $\mathrm{N}-\mathrm{SE}$ ) and $31.70 \%$ (in case of $\mathrm{N}-\mathrm{UE}_{\mathrm{W}}$ ). Ethanol extracts of autofermented samples had higher total extraction yield than native, while in the case of water extracts, autofermented samples had lower total extraction yield. In general, UE was proved to be more efficient for the recovery of chamomile compounds. Those results were in correlation with literature data. ${ }^{27}$
The yield of TP in explored samples was determined by using previously described Folin-Ciocalteu method and different yields of phenols were achieve for different solvents and techniques used (Table 2).

Autofermented samples were proved as much better sources of phenols independently on the extraction technique and solvent used (Table 2). Contents of the total phenolic compounds in A-UE (198.64 mg CAE/g) and A-SE (198.07 mg CAE/g) extracts were very similar, while total phenols content in autofermented sonificated water sample $\left(\mathrm{A}-\mathrm{UE}_{\mathrm{W}}\right)$ was about 1.5 times lower than in the autofermented sonificated ethanol (A-UE) sample (135.09 $\mathrm{mg} \mathrm{CAE} / \mathrm{g}$ ). In the case of native samples, the situation was the same, i.e. the total phenols content for the N-UE (133.26 mg CAE/g) was close to that of the N-SE (133.04 $\mathrm{mg} \mathrm{CAE} / \mathrm{g})$. Phenolic content in water extracts was the lowest (130.82 mg CAE/g). By comparing water and ethanol extracts obtained by ultrasonic extraction, water extracts were characterized with lower phenols content. The significant difference in phenols content was observed in autofermented sample, whereas this difference in the case of native samples was not so pronounced.

As a part of chemical composition analysis, the TF content in the native and in the autofermented CLF extracts was determined, as well. Flavonoids are important biomolecules which are present in surprisingly high concentrations in the plants. In this study their content was between $29.80 \mathrm{mg} \mathrm{RE} / \mathrm{g}\left(\mathrm{N}-\mathrm{UE}_{\mathrm{W}}\right)$ and $39.10 \mathrm{mg} \mathrm{RE} / \mathrm{mL}$ (A-UE). As well as in the case of phenols, all autofermented samples exhibited higher contents of flavonoid compounds. Results, presented in the Table 2, indicate the highest flavonoids content in ethanolic A-UE extract followed by A-SE and A-UE $\mathrm{UW}_{\mathrm{W}}$ extracts. In case of native samples, flavonoids content decreased as follows: N-SE > $\mathrm{N}-\mathrm{UE}>\mathrm{N}-\mathrm{UE}_{\mathrm{W}}$.

According to obtained results, it can be concluded that ultrasonic extraction technique was more efficient in comparison to Soxhlet extraction. This is certainly a consequence of increased liberation of the solutes from sam- 
ple matrix due to the cavitation phenomenon. Presented results show that regardless on the applied extraction technique or used solvent the autofermented samples have more phenolic bioactive compounds than the native ones.

\section{3. The Antioxidant Activity}

Polyphenols are well recognized for their health-promoting properties. Different studies indicated their wide spectrum of biological activities. ${ }^{28,29}$ Reducing properties of polyphenols as hydrogen or electron-donating agents predict their free-radical scavenging as well as antioxidant ability. The free-radical scavenging ability of obtained extracts (N-CLF and A-CLF) was tested using stable radical DPPH. Reducing power of tested extracts served as an indicator of their antioxidant ability. As shown in Table 3, all tested extracts showed an antioxidant potential in accordance with their total polyphenols content. Autofermented extracts exhibited better antioxidant capacity that could be linked to previously discussed polyphenols content. In this respect, the most potent extract was found to be the A-UE extract $\left(\mathrm{IC}_{50}=0.0270 \mathrm{mg} / \mathrm{mL}\right)$. On the other hand, the $\mathrm{N}-\mathrm{UE}_{\mathrm{W}}$ showed the highest $\mathrm{IC}_{50}$ value $(0.0601 \mathrm{mg} / \mathrm{mL})$ indicating the lowest antioxidant ability. However, significant differences among the extracts in this respect were not observed. The $\mathrm{IC}_{50}$ values increased in the following sequence: A-UE $(0.0270 \mathrm{mg} / \mathrm{mL})>$ A-SE $(0.0341 \mathrm{mg} / \mathrm{mL})$ $>$ A-UE $_{\mathrm{W}}(0.0418 \mathrm{mg} / \mathrm{mL})>\mathrm{N}-\mathrm{UE}(0.0528 \mathrm{mg} / \mathrm{mL})>$ $\mathrm{N}-\mathrm{SE}(0.0595 \mathrm{mg} / \mathrm{mL})>\mathrm{N}^{-U E_{\mathrm{W}}}(0.0601 \mathrm{mg} / \mathrm{mL})$.

The potential of the obtained extracts to fight against free radicals was also examined by determination of their reduction power. In the conducted analysis the electron-donating capacity of antioxidants was measured through the change of yellow colour of the test solutions to various shades of green and blue, depending on the reducing power of each sample. ${ }^{30}$ The presence of reducing agent causes a reduction of the $\mathrm{Fe}^{3+} /$ ferricyanide complex

Table 3. Antioxidative activity of chamomile extracts obtained by a different extraction technique

\begin{tabular}{lcccccc}
\hline Extracts & A-UE & N-UE & A-SE & N-SE & A-UEw & N-UEw \\
\hline $\begin{array}{l}\mathrm{DPPH} \\
\mathrm{IC}_{50}\end{array}$ & 0.027 & 0.053 & 0.034 & 0.060 & 0.042 & 0.060 \\
$(\mathrm{mg} / \mathrm{mL})$ & & & & & & \\
\hline $\begin{array}{l}\text { Reducing } \\
\text { power EC } \\
\text { (mg/mL) }\end{array}$ & 0.520 & 0.770 & 0.523 & 0.840 & 0.550 & 0.570 \\
\hline
\end{tabular}

A-UE ethanol extract of autofermented flowers prepared by ultrasound extraction; N-UE ethanol extract of native flowers prepared by ultrasound extraction; A-SE ethanol extract of autofermented flowers prepared by Soxhlet extraction; N-SE ethanol extract prepared from native flowers by Soxhlet extraction; $\mathbf{A}-\mathbf{U E}_{\mathrm{W}}$ aqueous extract prepared from autofermented flowers by ultrasound extraction; $\mathbf{N}-\mathbf{U E}_{\mathrm{W}}$ aqueous extract prepared from native flowers by ultrasound extraction to the ferrous form. The reducing power of extracts is a function of their concentration. All investigated N-CLF and A-CLF extracts showed good reducing power but as it could be expected, the highest reduction potential was detected in A-UE extracts with $\mathrm{EC}_{50}$ value of $0.520 \mathrm{mg} / \mathrm{mL}$, which represented the lowest value in all examined extracts.

The differences between $\mathrm{EC}_{50}$ values of A-UE $(0.520$ $\mathrm{mg} / \mathrm{mL})$ and A-SE $(0.523 \mathrm{mg} / \mathrm{mL})$ was insignificant, indicating similar reducing powers of those extracts. A-UE extracts had slightly higher $\mathrm{EC}_{50}$ value $(0.550 \mathrm{mg} / \mathrm{mL})$. Scavenging ability of native samples decreased in the following order: $\mathrm{N}-\mathrm{UE}_{\mathrm{W}}>\mathrm{N}-\mathrm{UE}>\mathrm{N}-\mathrm{SE}$. Focusing on the solvent influence it was evident that in the case of autofermented UE samples ethanol was superior, while in the case of native UE samples water was better solvent for extracting components with good reducing capacity. Autofermented samples again proved to be a better source of antioxidants in comparison to extracts obtained from the native CLF. Accordingly, it could be assumed that autofermented samples contain higher concentrations of reductones, which could react with free radicals to stabilize and block radical chain reactions.

\section{4. The Antiproliferative Activity of the CLF Extracts}

Chamomile flavonoids, the most important of which are apigenin conjugates, are recognized as natural compounds which exhibit broad biological activities. ${ }^{31}$ Apigenin acts by scavenging of free radicals and has significant antitumor activity in vitro and in vivo., ${ }^{5,32}$ Taking into account considerable biological potential of the apigenin ${ }^{11,18,27}$ its free form was increased in this study by bioconversion of the Ap-7-Glc before extraction processes. Antiproliferative capacity of obtained extracts was evaluated on normal and tumour cells during 48 and $72 \mathrm{~h}$, respectively. The statistically significant difference in the antiproliferative activity between autofermented and native extracts, and between treated and non-treated cells' growth were observed (Fig. 4 ). The observed effects were various and depended on the applied concentration and treated cells type as well. The obtained results show that all analysed extracts in two highest applied concentrations of 0.2 and $0.5 \mathrm{mg} / \mathrm{mL}$ reduced cells viability, particularly after $72 \mathrm{~h}$ of exposure. More potent extracts proved to be the autofermented extracts with highest content of apigenin, A-UE and A-SE, which exhibited better antioxidant capacity and the highest reduction potential as well. Extracts A-UE and A-SE, applied in the concentration of $0.1 \mathrm{mg} / \mathrm{mL}$ during 48 and $72 \mathrm{~h}$, inhibited cells' growth for near $60 \%$. The most sensible were treated leukemia cells K562, whose growth was significantly reduced (up to $80 \%$ ) after $48 \mathrm{~h}$ of exposure. Observed results correlate with published data based on the cytotoxic effect of apigenin on leukemia cells ${ }^{33,34}$ described significant influence of apigenin on the growth of myeloid (HL-60 and K562) com- 
a)

MDCK I

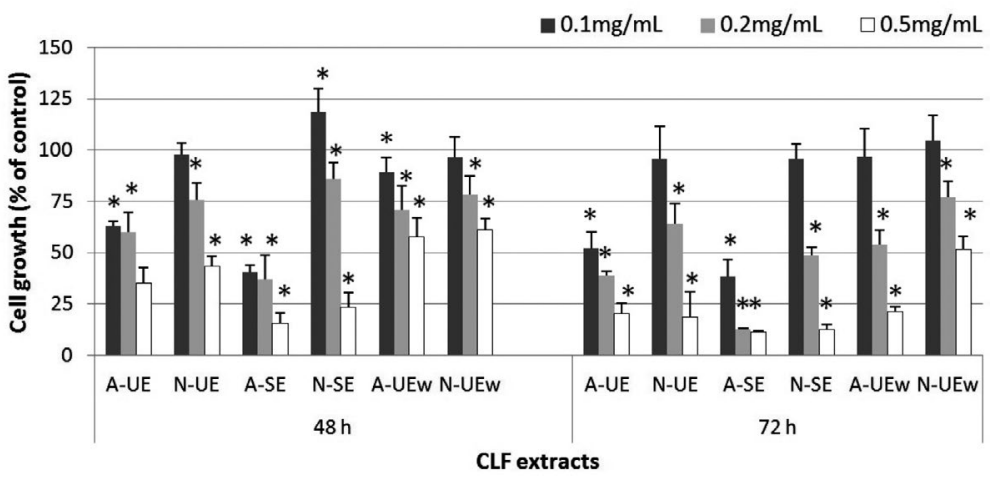

b)

HeLa

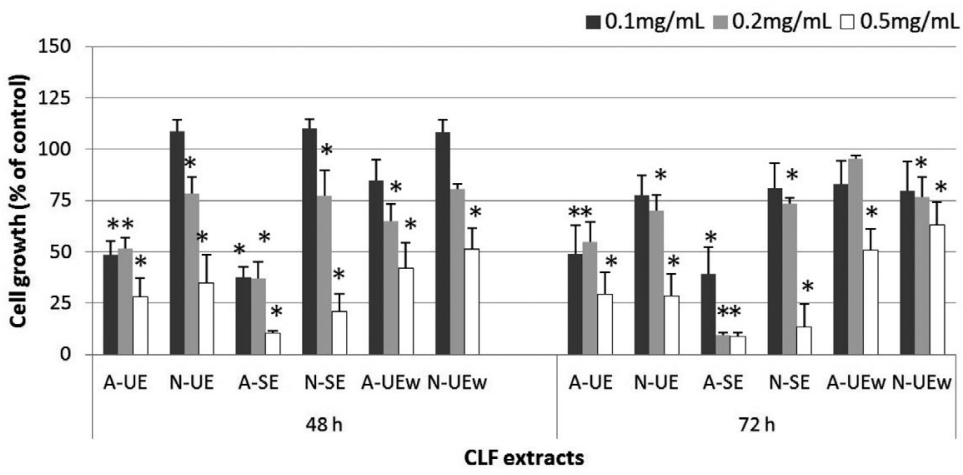

c)

NCl-H358

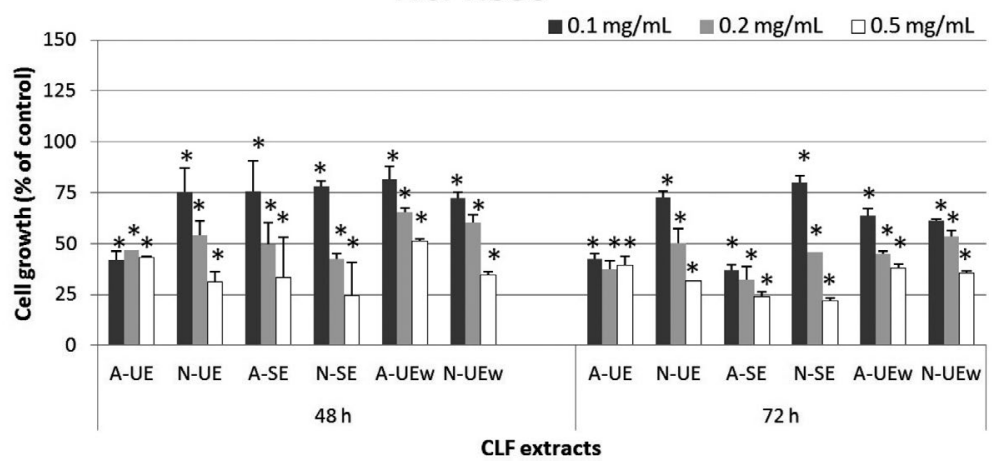

d)

K562

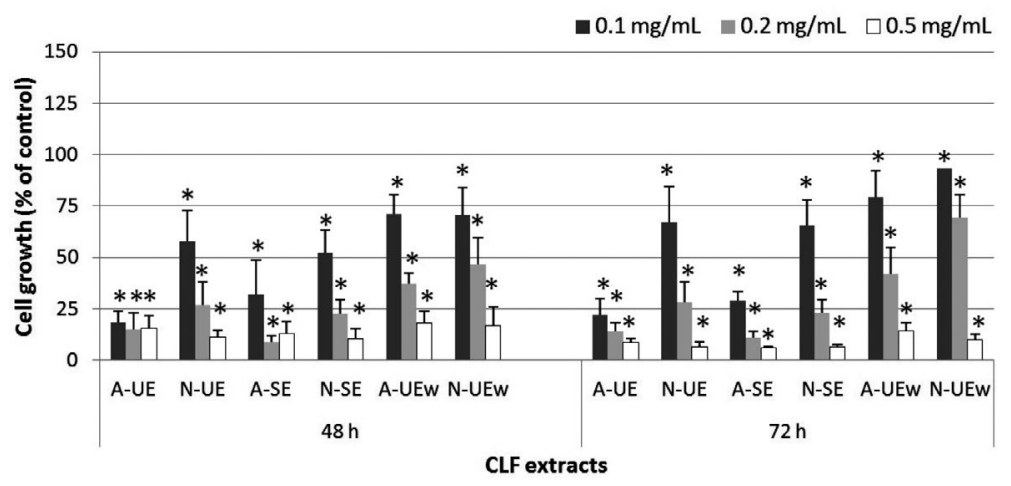

Figure 2. Cytotoxic effect of autofermented and native extracts in different cell lines. MDCK I (a), HeLa (b), NCI-H358 (c) and K562 (d) cells were treated with $0.5,0.2$ and $0.1 \mathrm{mg} / \mathrm{mL}$ of extract respectively. Cytotoxicity was assessed after 48 and $72 \mathrm{~h}$ by the MTT survival assay. Data represent mean value of three independent experiments done in triplicate. ${ }^{*}$ Statistically significant change $(\mathrm{p}<0.05)$ compared to control (non-treated) cells. 

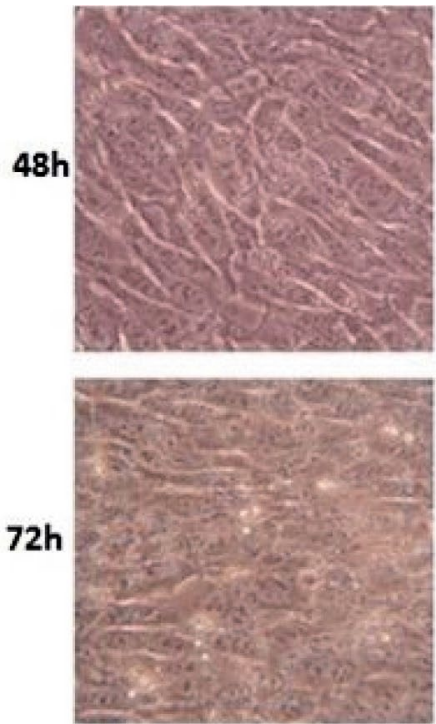

a)
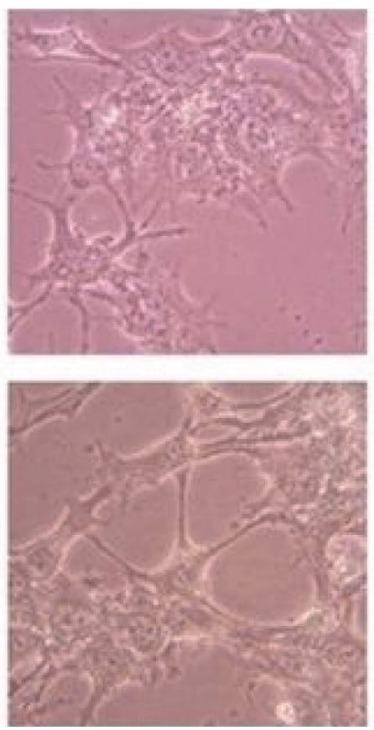

b)
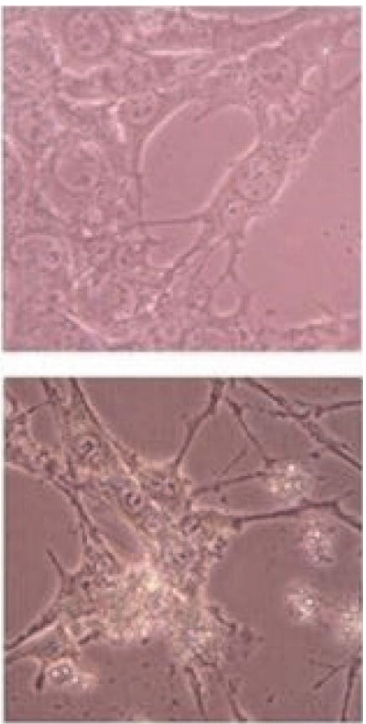

c)

Figure 3. Morphological changes in the HeLa cells. HeLa cells were treated with A-UE $(0.098 \mathrm{mg} / \mathrm{mL})$ and A-SE $(0.079 \mathrm{mg} / \mathrm{mL})$ for 48 and $72 \mathrm{~h}$. Native photographs are taken by the inverted microscope Olympus 1X51 with Olympus SP-500 UZ camera. Follows: a) control cells; b) A-UE extract and c) A-SE extract. Magnification $400 \mathrm{x}$.

pared to the erythroid (TF1) leukemia cells. Lower tested concentrations $(0.01,0.001$ and $0.0001 \mathrm{mg} / \mathrm{mL})$ only slightly affected the growth of treated cells (data not shown). The inhibitory effect of all tested extracts on normal cells was lower in comparison with effect on tumour cells after $48 \mathrm{~h}$ of exposure. That is in a good correlation with literature data where the selectivity in the antiproliferative activity of apigenin was described. $6,8,12,35$

Noticed morphological changes support observed cytotoxic results. A-UE and A-SE extracts applied at $\mathrm{GI}_{50}$ concentration evidently reduced the number of treated HeLa cells (Fig. 5) after 48 and $72 \mathrm{~h}$ of exposition.

\section{5. Proapoptotic Effects of the Autofermented CLF Extracts}

Among six different samples, ethanolic extracts of A-CLF, A-UE and A-SE, had the highest antiproliferative activity, thus those extracts were further subjected for testing on proapoptotic potential. In the $\mathrm{GI}_{50}$ concentrations, A-UE
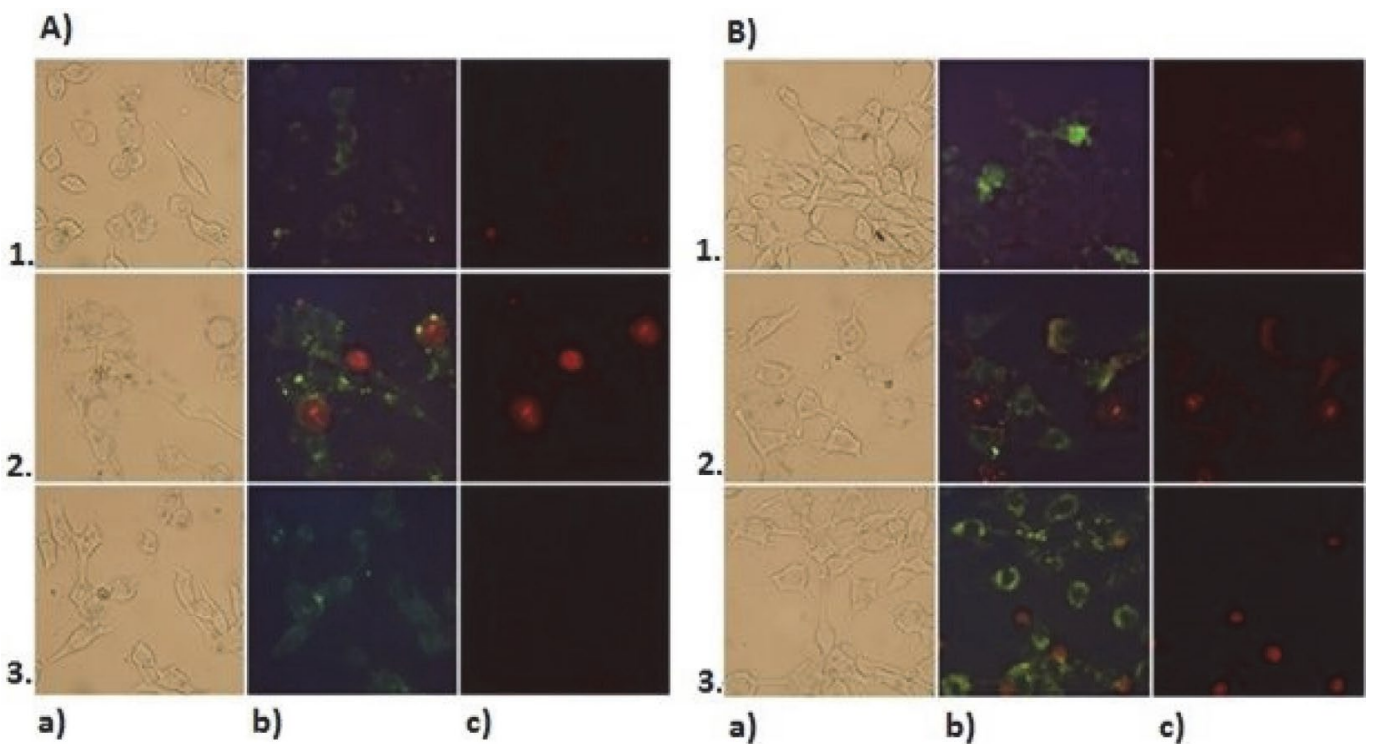

Figure 4. The fluorescent microscopy analysis of apoptosis caused by CLF extracts in the HeLa cells. HeLa cells were treated with A-UE (0.098 mg/ $\mathrm{mL}$ ) and A-SE $(0.079 \mathrm{mg} / \mathrm{mL})$ for $24 \mathrm{~h}(\mathrm{~A})$ and $48 \mathrm{~h}(\mathrm{~B})$. The cells were subsequently analyzed by the Carl Zeiss fluorescent microscope: a) visible light b) Annexin V-FITC (green fluorescence) and c) PI (red fluorescence); 1. apigenin standard (positive control) 2. A-UE extract and 3. A-SE extract. Magnification $400 \mathrm{x}$. 
$(0.098 \mathrm{mg} / \mathrm{mL})$ and A-SE $(0.079 \mathrm{mg} / \mathrm{mL})$ extracts, applied on HeLa cells for 24 and $48 \mathrm{~h}$, induced time depended apoptotic features. The exposure of phosphatidylserine (PS) on the external leaflet of the plasma membrane as an early marker of apoptosis, ${ }^{36}$ is visible in the HeLa cells with preserved cell shape (Fig. 6). The blebbing of the cell membrane was seen after $48 \mathrm{~h}$ of treatment with the A-UE extract. The standard compound apigenin in the applied concentration evoked less proapoptotic effect in comparison with tested extracts. The obtained results suggest that although apigenin has been proven as the compound able to inhibit tumour cell growth through apoptosis induction ${ }^{37,38,39}$ the treatment with autofermented CLF ethanolic extracts, which are mixtures of apigenin, its derivatives, and polyphenols as well, have improved proapoptotic efficacy.

\section{Conclusions}

Enzymatic hydrolysis assisted with plant's own enzyme (auto-fermentation) resulted in increased polyphenolic and flavonoid content in plant material. Moreover, the content of main flavone-apigenin was increased influencing higher antioxidant activity. Broad antiproliferative study of chamomile extracts proved high and doze-depended potential of all examined samples. However, extracts made by autofermented chamomile had significantly stronger impact on the treated tumour cells' growth reduction in comparison to the native CLF extracts. Leukemia cells showed to be more sensitive to all tested CLF extracts. The CLF extracts with highest antiproliferative efficacy induced morphological changes and apoptosis in the HeLa cells. Based on these results regarding the antiproliferative capacity of tested extracts, further research may be carried out to investigate the biological mechanisms of action of observed extracts and apigenin. Additionally, green and safe solvents were used in this study which in combination with enzyme-assisted ultrasound extraction of chamomile offers new platform for design of nutraceuticals and/or pharmaceuticals from chamomile.

\section{Acknowledgment}

The present work was carried out within the project of the Serbian Ministry of Education, Science and Technological Development, (Project No. TR 31013). Research was also supported by J.J. Strossmayer University of Osijek internal fund VIF-2015-MEFOS-2. The authors are grateful to Dr Dušan Adamović, Institute of Field and Vegetable Crops, Bački Petrovac, Serbia, for his support in supplying plant material.

\section{Conflict of interest}

The authors declare that there are no conflicts of interest.

\section{Reference}

1. R. H. Liu, Am. J. Clin. Nutr. 2003, 78, 3-6.

2. M. Abotaleb, S. Mathews Samuel, E. Varghese, S. Varghese, P. Kubatka, A. Liskova, D. Büsselberg. Cancers, 2019, 11, 1-39. DOI: $10.3390 /$ cancers 11010028

3. D. Raffa, B. Maggio, M. V. Raimondi, F. Plescia, G. Daidone. Eur J Med Chem., 2017, 142:213-228.

DOI:10.1016/j.ejmech.2017.07.034

4. D. Patel, S. Shukla, S. Gupta, Int. J. Oncol., 2007, 30, 233245.

5. S. Shukla, S. Gupta. Pharm. Res., 2010, 27, 962-978. DOI:10.1007/s11095-010-0089-7

6. K. Banerjee, M. Mandal. Redox Biology, 2015, 5, 153-162. DOI:10.1016/j.redox.2015.04.009

7. A. Kowalczyk, A. Bodalska, M. Miranowicz, K. Karłowicz-Bodalska. Adv Clin Exp Med., 2017, 26,1143-1146. DOI:10.17219/acem/41978

8. J. Madunić, I. Vrhovac Madunić, G. Gajski, J. Popić, V. Garaj Vrhovac. Cancer Lett., 2018, 413, 11-22.

DOI:10.1016/j.canlet.2017.10.041

9. T. D. Way, M. C. Kao, J. K. Lin, J. Biol. Chem., 2004, 279, 4479-4489. DOI:10.1074/jbc.M305529200

10. D. Kashyapa, A. Sharmab, H. Singh Tulic, K. Sakd, V. Kumar Garge, H. Singh Buttarf, W. N. Setzerg, G. Sethih. Journal of Functional Foods, 2018, 48, 457-471.

11. S. Shukla, S. Gupta, Shukla S, Gupta S, Bioactive Foods in Promoting Health, Fruits and Vegetables: Apigenin and cancer chemoprevention, London, Elsevier Ltd, 2009, pp. 663689. DOI:10.1016/B978-0-12-374628-3.00041-4

12. S. Shukla, S. Gupta, Cell Cycle, 2007, 6,1102-1114. DOI:10.4161/cc.6.9.4146

13. X. Yan, M. Qi, P. Li, Y. Zhan, H. Shao. Cell Biosci., 2017, 7:50, 1-16. DOI:10.1186/s13578-017-0179-x

14. T. C. Hsia, J. S. Yang, G. W. Chen, T. H. Chiu, H. F. Lu, M. D. Yang, F. S. Yu, K. C. Liu, K. C. Lai, C. C. Lin, J. G. Chung, Anticancer Res, 2009, 29, 309-318.

15. S. Gupta, F. Afaq, H. Mukhtar, Biochem. Biophys. Res. Commun, 2001, 287, 914-920. DOI:10.1006/bbrc.2001.5672

16. V. Švehlíková, R. N. Bennett, F. A. Mellon, P. W. Needs, S. Piacente, P. A. Kroon, Y. Bao, Phytochem, 2004, 65, 2323-2332. DOI:10.1016/j.phytochem.2004.07.011

17. J. K. Srivastava, E. Shankar, S. Gupta, Mol. Med. Rep., 2010, 3, 895-901.

18. A. Cvetanović, J. Švarc-Gajić, Z. Zeković, S. Savić, J. Vulić, P. Mašković,G. Ćetković, Planta, 2015, 242, 721-732.

DOI:10.1007/s00425-015-2308-2

19. Federal Office of Public Health (Beograd): Pharmacopoeia Jugoslavica editio quarta, (Ph. Jug. IV), 1984.

20. V. L. Singleton, J. A. J. Rossi, Am. J. Enology Vitic., 1965, 16, 144-158.

21. K. R. Markham, Methods in Plant Biochemistry: Flavones, flavonoids, and their glycosides, London: Academic Press Ltd., 1989, pp. 197-235.

DOI:10.1016/B978-0-12-461011-8.50012-3

22. A. Cvetanović, J. Švarc-Gajić, U. Gašić, Ž. Tešić, G. Zengin, 
Z. Zeković, S. Đurović, J. Supercrit. Fluids., 2017, 120, 32-42. DOI:10.1016/j.supflu.2016.10.012

23. S. Kečkeš, U. Gašić, T. Ćirković-Veličković, D. Milojković-Opsenica, M. Natić, Ž. Tešic, Food Chem, 2013, 138, 32-40. DOI:10.1016/j.foodchem.2012.10.025

24. J. C. Espín, C. Soler-Rivas, H. J. Wichers, J. Agric. Food Chem., 2000, 48, 648-656. DOI:10.1021/jf9908188

25. M. Oyaizu, J. Hum. Nutr. Diet., 1986, 44, 307-315.

DOI:10.5264/eiyogakuzashi.44.307

26. J. Kašnar-Šamprec, I. Ratkaj, K. Mišković, M. Pavlak, M. Baus-Lončar, S. Kraljević Pavelić, Lj. Glavaš-Obrovacj, B. Žinić, Invest. New Drugs, 2012, 30, 981-990.

DOI:10.1007/s10637-011-9657-x

27. P. C. Roy. Optimizing the Ultrasound Assisted Extraction of Phenolic Antioxidant Compounds from Centella Asiatica Leaves [Master's thesis], Kolkata (India): Jadavpur University, 2014.

28. D. R. Pavlović, S. Branković, N. Kovačević, D. Kitić, S. Veljković, Phytothe Res., 2011, 25, 749-754. DOI:10.1002/ptr.3460

29. P. H. Li, Y. W. Lin, W. C. Lu, J. M. Hu, D. W. Huang, Int. J. Food Prop., 2015, 19, 1786-1797.

30. I.C.F.R. Ferreira, P. Baptista, M. Vilas-Boas, L. Barros, Food Chem., 2007, 100, 1511-1516.

DOI:10.1016/j.foodchem.2005.11.043

31. S. Shukla, S. Gupta, See comment in PubMed Commons belowFree Radic. Biol. Med., 2008, 44, 1833-1845.
DOI:10.1016/j.freeradbiomed.2008.02.007

32. Y. Liao, W. Shen, G. Kong, H. Lv, W. Tao, P. Bo, PloS One, 2014, 9, e92007. DOI:10.1371/journal.pone.0092007

33. R. R. Ruela-de-Sousa, G. M. Fuhler, N. Blom, C. V. Ferreira, H. Aoyama, M. P. Peppelenbosch, Cell Death Dis, 2010, 1, e19. DOI:10.1038/cddis.2009.18

34. J. M. Mohammad Salmani, Z. Xiao-Ping, J. A. Jacob, C. BaoAn. Chin J Nat Med., 2017, 15, 321-329.

DOI:10.1016/S1875-5364(17)30052-3

35. X. Cao, B. Liu, W. Cao, W. Zhang, F. Zhang, H. Zhao, R. Meng, L. Zhang, R. Niu, X. Hao, B. Zhang, Chin. J. Cancer Res, 2013, $25,212-222$.

36. S.H. Lee, X.W. Meng, K.S. Flatten, D.A. Loegering, S.H. Kaufmann, Cell Death Differ., 2013, 20, 64-76. DOI: $10.1038 / \mathrm{cdd} .2012 .93$

37. P. W. Zheng, L. C. Chiang, C. C. Lin, Life Sci., 2005, 76, 13671379. DOI:10.1016/j.lfs.2004.08.023

38. F. Papachristou, E. Chatzaki, A. Petrou, I. Kougioumtzi, N. Katsikogiannis, A. Papalambros, G. Tripsianis, C. Simopoulosand, A. K. Tsaroucha, Chin. Med., 2013, 8, 1-9.

DOI:10.1186/1749-8546-8-9

39. R. P. Souza, P. de S. Bonfim-Mendonça, F. Gimenes, B. A. Ratti,V. Kaplum, M. L. Bruschi, C. V. Nakamura, S. O. Silva, S. S. Maria-Engler, M. E. L. Consolaro. Oxid Med Cell Longev., 2017, 2017, 1-18. DOI:10.1155/2017/1512745

\section{Povzetek}

Članek obravnava apigenin v cvetovih kamilice in njegovo biološko aktivnost. Nefermentirane nativne cvetove kamilic (N-CLF) in avto fermentirane cvetovi (A-CLF) smo ekstrahirali z različnimi tehnikami ekstrakcije (ultrazvok-UE, Soxhlet-SE) in različnimi topili. Dobljene ekstrakte smo primerjali glede na kemijsko sestavo in bio-potencial. Biološka aktivnost (antiproliferativni učinek, apoptoza) ekstraktov kamilice je bila raziskana na celičnih linijah MDCK I, HeLa, NCI-H358 in K562. V primerjavi z nativnimi ekstrakti so bili avtofermentirani ekstrakti opredeljeni z višjo vsebnostjo apigenina, večjim izkoristkom ekstrakcije, kot tudi večjo vsebnostjo skupnih fenolov in flavonoidov. Vsi ovrednoteni ekstrakti so pokazali pomembno antiproliferativno aktivnost proti tumorskim celičnim linijam. Najbolj občutljive so bile celice K562, ki so se po 48 urah izpostavljenosti zmanjšale za 80 \%. Morfološke spremembe in apoptozo smo odkrili v celicah HeLa, ki so bile izpostavljene ekstraktom A-UE $(0,098 \mathrm{mg} / \mathrm{ml})$ in A-SE $(0,079 \mathrm{mg} / \mathrm{ml})$.

Except when otherwise noted, articles in this journal are published under the terms and conditions of the Creative Commons Attribution 4.0 International License 